\title{
The Care of Patients with Chronic Kidney Disease
}

\author{
What Must We Do and Who Should Do It?
}

C hronic kidney disease (CKD) is a public health problem. The National Kidney Foundation (NKF) Kidney Disease Outcomes Quality Initiative (K/DOQI) has recently published K/DOQI Clinical Practice Guidelines for Chronic Kidney Disease: Evaluation, Classification, and Stratification, ${ }^{1}$ which provides definitions, prevalence estimates, and an action plan for stages of chronic kidney disease (Table 1). End-stage renal disease (ESRD) is defined as patients treated by dialysis and kidney transplantation and corresponds approximately to the stage of kidney failure (stage 5, glomerular filtration rate $\left[\right.$ GFR] $<15 \mathrm{~mL} / \mathrm{min} / 1.73 \mathrm{~m}^{2}$ or treated by dialysis). According to the United States Renal Data System, the incidence in the United States was 89,252 new patients in 1999. The prevalence of ESRD was 340,261 as of December $31,1999,{ }^{2}$ and the projected number by the year 2010 is over $600,000 .^{3}$ Hospitalization rates for patients with ESRD are high compared to age- and riskadjusted comparative cohorts, and the life expectancy of dialysis patients in the United States is $16 \%$ to $37 \%$ of the age-, gender-, and race-matched population. The total cost was $\$ 17.9$ billion in $1999,{ }^{2}$ and has been projected to be in excess of $\$ 28$ billion by the year $2010 .^{3}$

The prevalence of earlier stages of CKD is even higher. Estimates for decreased GFR (corresponding to Stages 3 and 4) range from 0.8 to 8 million, depending on the cutoff values for serum creatinine (SCr) or estimated GFR. ${ }^{1,4}$ There may be as many as 20.3 million individuals with kidney damage, estimated by the presence of microalbuminuria or albuminuria (Stages 1 and 2). ${ }^{1}$ Therapeutic interventions implemented early in the course of CKD have been demonstrated to be effective in delaying or preventing the adverse outcomes of chronic kidney disease. ${ }^{5-7}$ The clinical action plan recommended by the NKF-K/DOQI clinical practice guideline focuses on: early detection, diagnosis, and treatment; slowing progression to kidney failure; detection and treatment of complications; preparation for and timely initiation of kidney replacement therapy; and diagnosis and treatment of cardiovascular disease and other comorbid conditions.

The article by Winkelmayer et al. ${ }^{8}$ focuses on selected comorbid conditions that could be tracked through administrative data. They demonstrate a low prevalence of preventive and screening tests among patients with CKD in the year prior to and in the year after the start of renal replacement therapy. They note that screening for cancers (breast and cervical among women, and prostate among men), and preventive measures for diabetes care (eye exam and hemoglobin $\mathrm{AlC}$ ) were well below the rates for a general managed care population in the same geographic area. Potential explanations they put forth were physician inattentiveness, fatalism about patient outcomes, poor patient adherence to testing, and inadequate financial coverage for these tests. They conclude that increased testing may result in improved health outcomes among patients with end-stage renal disease.

Other reports have suggested that care of patients with CKD in the United States may be suboptimal. ${ }^{9}$ We agree with the authors' discussion of possible causes of suboptimal care in the patients they studied. We suggest that the reported lack of comprehensive health care management offered to patients with CKD may be addressed by a more effective collaboration between the patients' primary care physicians and the specialists who participate in their care, following the action plan proposed in the NKF-K/DOQI guidelines.

\section{EARLY DETECTION, DIAGNOSIS, AND TREATMENT}

Detection of earlier stages of CKD, and classification of stages of $\mathrm{CKD}$, can be done simply with routine laboratory testing: urine testing for albuminuria or proteinuria and estimation of GFR from serum creatinine. The NKF Guidelines for CKD recommend using a spot albumin-tocreatinine ratio, or albumin-specific dipsticks on a first morning void specimen to screen for $\mathrm{CKD}$, and emphasize the need to estimate GFR from SCr, since SCr alone may misrepresent the level of kidney function, because it is related to muscle mass, dietary intake, and age. Initial diagnosis should focus on distinguishing among patients with diabetic kidney disease, nondiabetic kidney diseases, and diseases in kidney transplant recipients. Recent reviews and guidelines are helpful for the initial diagnosis and treatment of these conditions. ${ }^{10-13}$

\section{ESTIMATING AND SLOWING PROGRESSION OF CHRONIC KIDNEY DISEASE IN ADULTS}

In general, GFR should be estimated from serum creatinine at least yearly in patients with $\mathrm{CKD}$ and more often in patients with: GFR $<60 \mathrm{~mL} / \mathrm{min} / 1.73 \mathrm{~m}^{2}$; GFR decline $\geq 4 \mathrm{~mL} / \mathrm{min}$ per year; risk factors for faster progression; ongoing treatment to slow progression; and exposure to risk factors for acute GFR decline. Numerous clinical trials have shown that blood pressure control, angiotensin-converting enzyme (ACE) inhibition, and glucose control in diabetics, are generally effective in retarding the development and progression of kidney disease; dietary protein restriction remains controversial. ${ }^{14-20}$ Treatments to slow the progression of chronic kidney disease in adults are summarized in Table 2.

Adequate blood pressure control may be the single most important intervention in slowing the progression of renal disease; Table 2 outlines blood pressure goals. ${ }^{21-23}$ Angiotensin-converting enzyme inhibitors have been 
Table 1. Classification, Prevalence and Clinical Action Plan for Chronic Kidney Disease*

\begin{tabular}{|c|c|c|c|c|}
\hline Stage & Description & $\begin{array}{c}\text { GFR } \\
\left(\mathrm{mL} / \mathrm{min} / 1.73 \mathrm{~m}^{2}\right)\end{array}$ & $\begin{array}{c}\text { Prevalence, } \\
\mathrm{n} \text { in } 1,000 \mathrm{~s}(\%)\end{array}$ & Action Plan \\
\hline & At increased risk & $\geq 90$ (CKD risk factors) & $?$ & Screening, CKD risk reduction \\
\hline 2 & $\begin{array}{l}\text { Kidney damage } \\
\text { with mild } \Downarrow \mathrm{GFR}^{\dagger}\end{array}$ & $60-89$ & $5,300(3.0)$ & Estimating progression \\
\hline 4 & Severe $\Downarrow$ GFR & $15-29$ & $400(0.2)$ & Preparation for kidney replacement therapy \\
\hline 5 & Kidney failure & $<15$ (or dialysis) & $300(0.1)$ & Replacement (if uremia present) \\
\hline
\end{tabular}

* Data for Stages 1-4 from NHANES III (1988-1994). ${ }^{1}$ Population of 177 million with age $\geq 20$ years. Data for Stage 5 from U.S. Renal Data System $(1998)^{3}$ includes approximately 230,000 patients treated by dialysis and assumes 70,000 additional patients not on dialysis. Percentages total $>100 \%$ because NHANES III may not have included patients on dialysis. GFR estimated from serum creatinine using Modification of Diet in Renal Disease Study equation based on age, gender, race and calibration for serum creatinine.

${ }^{\dagger}$ For Stages 1 and 2, kidney damage was assessed by spot albumin-to-creatinine ratio $>17 \mathrm{mg} / \mathrm{g}$ (men) or $>25 \mathrm{mg} / \mathrm{g}$ (women) on 2 measurements. Albuminuria was persistent in $54 \%$ of individuals with $\mathrm{GFR} \geq 90 \mathrm{~mL} / \mathrm{min} / 1.73 \mathrm{~m}^{2}(\mathrm{n}=102)$ and $73 \%$ of individuals with GFR $60-89 \mathrm{~mL} / \mathrm{min} / 1.73 \mathrm{~m}^{2}(\mathrm{n}=44)$.

Adapted from National Kidney Foundation, K/DOQI Clinical Practice Guidelines for Chronic Kidney Disease: Evaluation, Classification and Stratification. ${ }^{1}$

GFR, glomerular filtration rate; CKD, chronic kidney disease; CVD, cardiovascular disease.

shown to be of benefit beyond their antihypertensive action in established diabetic and nondiabetic nephropathy, ${ }^{6,24-26}$ and more recently, angiotensin II receptor blockers have been shown to be beneficial for delaying progression of kidney disease, ${ }^{27,28}$ The choice of other antihypertensive medications should take into consideration co-existing conditions, potential side effects, and the predisposition of the elderly to orthostatic hypotension, since all available antihypertensives are potentially effective.

In patients with insulin-dependent diabetes mellitus (IDDM), intensive glycemic control can prevent or delay the development of microalbuminuria and the progression from microalbuminuria to albuminuria. ${ }^{17,19}$ Optimal blood glucose control is recommended in all diabetic patients even before the onset of microalbuminuria, and is recommended for patients with microalbuminuria, because it reduces the occurrence of nephropathy by
$40 \%$ to $60 \% .^{17,30}$ It is not clear whether good glycemic control affects progression of nephropathy in its later stages. ${ }^{14,31}$ The American Diabetes Association has set forth a position statement with guidelines for the care of patients with diabetes mellitus (DM), ${ }^{11}$ with specific attention to the complication of kidney disease. The reader can access complete guidelines for comprehensive information available on the internet at www.diabetes.org. The benefits of intensive glycemic control should be balanced with the risks associated with severe hypoglycemia, particularly among patients with advanced renal disease and the elderly. ${ }^{29}$

The NKF-K/DOQI guidelines for CKD state that "there is insufficient evidence to recommend for or against routine prescription of dietary protein restriction for the purpose of slowing the progression of chronic kidney disease." 1 The largest randomized controlled trial performed to date, the Modification of Diet in Renal

Table 2. Treatments to Slow the Progression of Chronic Kidney Disease in Adults

\begin{tabular}{|c|c|c|c|}
\hline & $\begin{array}{c}\text { Diabetic } \\
\text { Kidney Disease }\end{array}$ & Nondiabetic Kidney Disease & $\begin{array}{l}\text { Kidney Disease in } \\
\text { the Transplant }\end{array}$ \\
\hline Strict glycemic control & Yes* & NA & Not tested \\
\hline $\begin{array}{l}\text { ACE-inhibitors or } \\
\text { angiotensin-receptor blockers }\end{array}$ & Yes & $\begin{array}{c}\text { Yes } \\
\text { (greater effect in patients with proteinuria) }\end{array}$ & Not tested \\
\hline Strict blood pressure control & $\begin{array}{l}\text { Yes } \\
<125 / 75 \mathrm{~mm} / \mathrm{Hg}\end{array}$ & $\begin{array}{c}\text { Yes } \\
<130 / 85 \mathrm{~mm} / \mathrm{Hg} \\
\text { (greater effect in patients with proteinuria) } \\
\text { or } \\
<125 / 75 \mathrm{~mm} / \mathrm{Hg} \\
\text { in patients with proteinuria }\end{array}$ & Not tested \\
\hline Dietary protein restriction & Inconclusive & Inconclusive & Not tested \\
\hline
\end{tabular}

* Prevents or delays the onset of diabetic kidney disease. Inconclusive with regard to progression of established disease.

ACE, angiotensin-converting enzyme. 
Disease Study, showed overall little benefit in patients with moderate (GFR $\geq 25 \mathrm{~mL} / \mathrm{min} / 1.73 \mathrm{~m}^{2}$ ) and advanced kidney failure (GFR $\left.<25 \mathrm{~mL} / \mathrm{min} / \mathrm{m}^{2}\right) .{ }^{20}$ However, subsequent meta-analyses suggested there may be some benefit. ${ }^{32,33}$ Individual decision making is recommended, after discussion of risks and benefits. This is in agreement with the NKF-K/DOQI Clinical Practice Guidelines on Nutrition in Chronic Renal Failure, which recommends consideration of a low-protein diet $(0.6 \mathrm{~g} / \mathrm{kg} / \mathrm{d})$ for patients with GFR in the range of CKD Stage $4-5 .{ }^{34}$

\section{CARDIOVASCULAR DISEASE RISK ASSESSMENT AND REDUCTION}

In the last annual data report of the U.S. Renal Data System, the death rate from ischemic or atherosclerotic heart disease was 21.5 per 1,000 patient-years at risk. In addition, hospitalizations due to cardiovascular causes far outpace hospitalizations for other causes, accounting for $36 \%$ of all hospitalizations among ESRD patients. ${ }^{2}$ Similarly, among patients with earlier stages of CKD at one center, cardiovascular disease (CVD) causes were the most common primary cause for hospitalizations. ${ }^{35}$ Furthermore, CVD begins early in the course of CKD, and the prevalence increases with worsening kidney function: $30 \%$ to $45 \%$ of individuals with creatinine clearances $<50 \mathrm{~mL} /$ min, ${ }^{36}$ and $74 \%$ of patients starting dialysis ${ }^{37}$ are reported as having left ventricular hypertrophy. Among patients starting dialysis, $36 \%$ to $42 \%$ percent have had past myocardial infarction or coronary revascularization. ${ }^{38}$

The NKF-K/DOQI guidelines recommend that patients with CKD should be considered in the "highest-risk group" for CVD risk reduction. CVD and progression of CKD share many risk factors, and the relevant interventions target both of these conditions. However, few patients with CKD have been included in population-based epidemiologic studies of CVD or long-term randomized clinical trials. The NKF Task Force on Cardiovascular Disease in Chronic Renal Disease recommended risk factor reduction for "traditional" risk factors based largely on extrapolation from the general population and evidence of safety and efficacy of interventions on risk factor levels in chronic kidney disease. It was the opinion of the CVD Task Force and the CKD Work Group that extrapolation from the general population to patients with chronic kidney disease is most appropriate for patients with Stages 1-4 CKD and less (but possibly still) appropriate for patients with kidney failure (Stage $5 \mathrm{CKD}$ ). A partial list of "traditional" CVD risk factors and risk factor reduction strategies that are potentially safe and effective for patients with CKD is shown in Table 3.

\section{DETECTING AND MANAGING COMPLICATIONS OF DECREASED GFR ( $\left.<60 \mathrm{ML} / \mathrm{MIN} / 1.73 \mathrm{M}^{2}\right)$}

Many complications begin to occur once the GFR falls below $60 \mathrm{~mL} / \mathrm{min} / 1.73 \mathrm{~m}^{2}$, and can be prevented or delayed by early detection and treatment. High blood pressure is both a cause and a complication of CKD, and is
Table 3. Risk Factors for Chronic Kidney Disease and Cardiovascular Disease and Associated Interventions

\begin{tabular}{|c|c|}
\hline "Traditional" Risk Factors & Intervention \\
\hline Family history of CVD & Screening \\
\hline $\begin{array}{l}\text { Hyperglycemia (in patients } \\
\text { with diabetes) }\end{array}$ & Diet, insulin, and oral agents \\
\hline Hypertension & Antihypertensive therapy \\
\hline Menopause & Possibly estrogen replacement \\
\hline Physical inactivity & Regular exercise regimen \\
\hline Psychosocial stress & Possibly stress reduction \\
\hline $\begin{array}{l}\text { Renin-angiotensin } \\
\text { system activity }\end{array}$ & $\begin{array}{l}\text { Angiotensin-converting } \\
\text { enzyme inhibitors or } \\
\text { angiotensin-receptor blockers }\end{array}$ \\
\hline Smoking (tobacco use) & $\begin{array}{l}\text { Counseling and nicotine } \\
\text { replacement }\end{array}$ \\
\hline Thrombogenic factors & Antiplatelet agents (aspirin) \\
\hline $\begin{array}{l}\text { Elevated total or LDL } \\
\text { cholesterol, triglycerides }\end{array}$ & Lipid-lowering diets and drugs \\
\hline
\end{tabular}

Adapted from National Kidney Foundation, K/DOQI Clinical Practice Guidelines for Chronic Kidney Disease: Evaluation, Classification and Stratification. ${ }^{1}$ Modified from the NKF Task Force on Cardiovascular Disease in Chronic Renal Disease.

associated with a faster rate of loss of kidney function, and development of CVD. Other complications include anemia, bone disease related to abnormal calcium and phosphorus metabolism, malnutrition or hypoalbuminemia, decreased functioning and well-being, and neuropathy. The presence of and severity of anemia is related to the duration and extent of kidney failure. Likewise, protein-energy malnutrition and abnormal calcium/phosphorus metabolism tend to be proportional to the degree of kidney function abnormality. Although objective findings of neuropathy are present in $15 \%$ to $85 \%$ of patients with varying degrees of CKD, it rarely becomes symptomatic unless the GFR is less than $12-20 \mathrm{~mL} / \mathrm{min} / 1.73 \mathrm{~m}^{2}$. Whether decreased functioning and well-being are directly related to level of kidney function or are affected by socioeconomic factors and associated comorbid conditions is unclear. Only anemia and malnutrition have been firmly associated with adverse outcomes. ${ }^{39-47}$ Table 4 lists additional clinical evaluations that should be performed in adults with GFR $<60 \mathrm{~mL} / \mathrm{min} / 1.73 \mathrm{~m}^{2}$ to detect and manage complications of decreased kidney function.

\section{CO-MANAGEMENT BY PRIMARY CARE PHYSICIANS AND SPECIALISTS}

The evaluation and management of patients with CKD requires diagnosis and understanding of the related comorbid conditions, complications, and risks for loss of kidney function and development or worsening of CVD. Frequently the primary care provider will make the diagnosis of kidney disease, but may require the assistance of a nephrologist to define the cause if not immediately apparent. Given the high prevalence of CKD and the importance of early implementation of interventions to 
Table 4. Additional Clinical Interventions for Adults with GFR $<60 \mathrm{~mL} / \mathrm{min} / 1.73 \mathrm{~m}^{2}$

\begin{tabular}{|c|c|c|}
\hline Clinical Problem & Parameters to Assess & $\begin{array}{l}\text { Possible Additional Parameters to Assess } \\
\text { (See Other Guidelines) }\end{array}$ \\
\hline Anemia & Hemoglobin & $\begin{array}{l}\text { If anemic: } \\
\text { - Red blood cell indices } \\
\text { - Reticulocyte count } \\
\text { - Iron studies (serum iron, total binding capacity, percent } \\
\text { transferrin saturation and ferritin) } \\
\text { - Test for occult blood in stool } \\
\text { - Medical evaluation for comorbid conditions }\end{array}$ \\
\hline Malnutrition & $\begin{array}{l}\text { Weight } \\
\text { Serum albumin } \\
\text { Dietary history } \\
\text { Subjective global assessment }\end{array}$ & $\begin{array}{l}\text { If malnourished: } \\
\text { - 24-h urine collection for urea nitrogen excretion } \\
\text { - Food recall/records for protein and total energy intake } \\
\text { - Medical evaluation for comorbid conditions }\end{array}$ \\
\hline Bone Disease & $\begin{array}{l}\text { Serum parathyroid hormone } \\
\text { Serum calcium } \\
\text { Serum phosphorus }\end{array}$ & $\begin{array}{l}\text { If abnormal: } \\
\text { - Vitamin D levels } \\
\text { - Bone x-rays } \\
\text { - DEXA scan }\end{array}$ \\
\hline $\begin{array}{l}\text { Reduced functioning and } \\
\text { well-being* }\end{array}$ & $\begin{array}{l}\text { Standardized, self-administered } \\
\text { instruments such as: } \\
\text { Dartmouth COOP Charts } \\
\text { DUKE/DUSOI } \\
\text { SF-36 } \\
\text { KDQOL }\end{array}$ & $\begin{array}{l}\text { If abnormal: } \\
\text { - Medical evaluation for comorbid conditions } \\
\text { - Self-management education } \\
\text { - Physical rehabilitation } \\
\text { - Mental health treatment } \\
\text { - Social support } \\
\text { - Vocational rehabilitation }\end{array}$ \\
\hline
\end{tabular}

* Symptoms, physical functioning, depression, employment, usual activities, and social functioning.

Adapted from National Kidney Foundation, K/DOQI Clinical Practice Guidelines for Chronic Kidney Disease: Evaluation, Classification and Stratification. ${ }^{1}$

delay its progression and the development of CVD, it is necessary to provide tools for primary care providers to enable them to undertake much of this care. The NKF guidelines for CKD seek to provide a road map for the care of patients with CKD via the clinical action plan (the full text of the K/DOQI clinical practice guidelines is available on the internet at www.kidney.org). Referral to the specialist for co-management or consultation should be made if the patient evaluation cannot be carried out, or the clinical action plan cannot be devised or implemented. In general, patients with $\mathrm{GFR}<30 \mathrm{~mL} / \mathrm{min} / 1.73 \mathrm{~m}^{2}$ should be referred to a nephrologist for education regarding alternatives for the management of ESRD and preparation for such treatment. - ANNAMARIA T. KAUSZ, MD, MS and ANDREW S. LEVEY, MD, Division of Nephrology, Tufts-New England Medical Center, Boston, Mass.

\section{REFERENCES}

1. The K/DOQI Clinical Practice Guidelines on Chronic Kidney Disease Work Group. K/DOQI clinical practice guidelines for chronic kidney disease. Evaluation, classification and stratification. Am J Kidney Dis. 2002;39:S1-S266.
2. U.S. Renal Data System. 2001 Annual Data Report: Atlas of EndStage Renal Disease in the United States. Bethseda, Md: National Institutes of Health, National Institute of Diabetes and Digestive and Kidney Diseases; 2001.

3. U.S. Renal Data System. 2000 Annual Data Report: Atlas of EndStage Renal Disease in the United States. Bethseda, Md: National Institutes of Health, National Institute of Diabetes and Digestive and Kidney Diseases; 2000.

4. Jones C, McQuillan G, Kusek J, et al. Serum creatinine levels in the US population: Third National Health and Nutrition Examination Survey. Am J Kidney Dis. 1998;32:992-9 (erratum: Am J Kidney Dis. 2000;35:178).

5. Modification of Diet in Renal Disease Study Group. Effects of dietary protein restriction on the progression of moderate renal disease in the MDRD Study. J Am Soc Nephrol. 1996;7: 2616-26.

6. Giatras I, Lau J, Levey AS. Effect of angiotensin-converting enzyme inhibitors on the progression of non-diabetic renal disease: a meta-analysis of randomized trials. Ann Intern Med. 1997;127:337-45.

7. Pereira BJG. Optimization of pre-ESRD care: the key to improved dialysis outcomes. Kidney Int. 2000;57:351-65.

8. Winkelmayer WC, Owen Jr W, Glynn RJ, Levin R, Avorn J. Preventive health care measures before and after start of renal replacement therapy. J Gen Intern Med. 2002;17:588-95.

9. Obrador GT, Ruthazer R, Arora P, Kausz A, Pereira BJG. Prevalence of and factors associated with sub-optimal care prior 
to initiation of dialysis in the United States. J Am Soc Nephrol. 1999;10:1793-800.

10. Kasiske B, Vazquez M, Harmon W, et al. Clinical practice guidelines of the American Society of Transplantation: recommendations for the outpatient surveillance of renal transplant recipients. J Am Soc Nephrol. 2000;11:S1-S86.

11. Standards of Medical Care for Patients with Diabetes Mellitus. Position statement. Clinical practice recommendations. Diabetes Care. 2001;24(Suppl 1):33-43.

12. Levey A Clinical practice series: non-diabetic kidney disease. N Engl J Med. 2002. In press.

13. Howard A. Long-term management of the renal transplant recipient: optimizing the relationship between the transplant center and the community nephrologist. Am J Kidney Dis. 2001; 38:S1-S55.

14. Viberti GC, Bilous RW, MacKintosh D, Bending JJ, Keen H. Long term correction of hyperglycaemia and progression of renal failure in insulin dependent diabetes. BMJ. 1983;286:598-602.

15. Lewis EJ, Hunsicker LG, Bain RP, Rohde RD. The effect of angiotensin-converting enzyme inhibition on diabetic nephropathy. N Engl J Med. 1993;329:1456-62.

16. Laffel LMB, McGill JB, Gans D. The beneficial effect of angiotensinconverting enzyme inhibition with captopril on diabetic nephropathy in normotensive IDDM patients with microalbuminuria. Am J Med. 1995;99:497-504.

17. The Diabetes Control and Complications Research Group. Effect of intensive therapy on the development and progression of diabetic nephropathy in the Diabetes Control and Complications Trial. Kidney Int. 1995;47:1703-20.

18. Parving HH, Andersen AR, Smidt UM, Homel E, Mathiesen ER, Svendsen PA. Effect of antihypertensive treatment on kidney function in diabetic nephropathy. BMJ. 1987;294:1443-7.

19. Christensen CK, Mogensen CE. Effect of antihypertensive treatment on progression of incipient diabetic nephropathy. Hypertension. 1985; 7:109-13.

20. Klahr S, Levey AS, Beck GJ, et al. The effects of dietary protein restriction and blood-pressure control on the progression of chronic renal disease. N Engl J Med. 1994;330:877-84.

21. Mogensen CE. Progression of nephropathy in long-term diabetics with proteinuria and effect of initial anti-hypertensive treatment. Scand J Clin Lab Invest. 1976;36:383-88.

22. Christlieb AR, Warram JH, Krolewski AS, et al. Hypertension: the major risk factor in juvenile-onset insulin-dependent diabetics. Diabetes. 1981;30(Suppl 2):90-6.

23. Peterson JC, Adler S, Burkart JM, et al. Blood pressure control, proteinuria, and the progression of renal disease. The Modification of Diet in Renal Disease Study. Ann Intern Med. 1995;123: 754-62.

24. Maschio G, Alberti D, Janin G, et al. Effect of the angiotensinconverting enzyme inhibitor benazepril on the progression of chronic renal insufficiency. The Angiotensin-Converting-Enzyme Inhibition in Progressive Renal Insufficiency Study Group. N Engl J Med. 1996;334:939-45.

25. Zuchelli P, Zucalla A, Borghi M, et al. Long-term comparison between captopril and nifedipine in the progression of renal insufficiency. Kidney Int. 1992;42:452-8.

26. Hannedouche T, Landais P, Goldfarb B, et al. Randomised controlled trial of enalapril and beta blockers in non-diabetic chronic renal failure. BMJ. 1994;309:833-7.

27. Brenner B, Cooper M, deZeeuw D, et al. Effects of losartan on renal and cardiovascular outcomes in patients with type 2 diabetes and nephropathy. N Engl J Med. 2001;345:861-9.
28. Parving HH, Lehnert H, Brochner-Mortensen J, Gomis R, Andersen S, Arner P. The effect of irbesartan on the development of diabetic nephropathy in patients with type 2 diabetes. $\mathrm{N}$ Engl $\mathrm{J}$ Med. 2001;345:870-8.

29. The Diabetes Control and Complications Trial Research Group The effect of intensive treatment of diabetes on the development and progression of long-term complications in insulin-dependent diabetes mellitus. N Engl J Med. 1993;329:977-86.

30. Wang PH, Lau J, Calmers TC. Meta-analysis of effects of intensive blood-glucose control on late complications of type I diabetes. Lancet. 1993;341:1306-9.

31. Breyer JA. Diabetic nephropathy in insulin-dependent patients. Am J Kidney Dis. 1992;20:533-47.

32. Pedrini MT, Levey AS, Lau J, Chalmers TC, Wang PH. The effect of dietary protein restriction on the progression of diabetic and nondiabetic renal diseases: a meta-analysis. Ann Intern Med. 1996; 124:627-32.

33. Kasiske BL, Lakatua JDA, Ma JZ, Louis TA. A meta-analysis of the effects of dietary protein restriction on the rate of decline in renal function. Am J Kidney Dis. 1998;31:954-61.

34. The K/DOQI Nutrition Work Group. K/DOQI clinical practice guidelines for nutrition in chronic renal failure. Am J Kidney Dis. 2000;35(Suppl 2):S56-64

35. Khan S, Kazmi H, Abichandani R, Tighiouart H, Pereira B, Kausz A. Health care utilization among patients with chronic kidney disease. Kidney Int. 2002;62:229-36.

36. Levin A, Singer J, Thompson CR, Ross H, Lewis M. Prevalent left ventricular hypertrophy in the predialysis population: identifying opportunities for intervention. Am J Kidney Dis. 1996;27:347-54.

37. Foley RN, Parfrey PS, Harnett JD, et al. Clinical and echocardiologic disease in patients starting end-stage renal disease therapy. Kidney Int. 1995;47:186-92.

38. U.S. Renal Data System. USRDS 1997 Annual Data Report. Bethesda, Md: National Institutes of Health, National Institute of Diabetes and Digestive and Kidney Diseases; 1997.

39. Port F. Morbidity and mortality in dialysis patients. Kidney Int 1994;46:1728-37.

40. McCusker FX, Teehan BP, Thorpe KE, Keshaviah PR, Churchill DN, for the Canada-USA (CANUSA) Peritoneal Dialysis Study Group. How much peritoneal dialysis is required for the maintenance of a good nutritional state? Kidney Int. 1996;50:S56-61.

41. Churchill D, Taylor D, Cook R, et al. Canadian hemodialysis morbidity study. Am J Kidney Dis. 1992;19:214-34.

42. Foley RN, Parfrey PS, Harnett JD, Kent GM, Murray DC Barre PE. The impact of anemia on cardiomyopathy, morbidity and mortality in end-stage renal disease. Am J Kidney Dis. 1996; 28:53-61

43. Churchill DN, Muirhead N, Goldstein M, et al. Effect of recombinant human erythropoietin on hospitalization of hemodialysis patients. Clin Nephrol. 1995;43:184-8.

44. Madore F, Lowrie E, Brugnara C, et al. Anemia in hemodialysis patients: variables affecting this outcome predictor. J Am Soc Nephrol. 1997;8:1921-9.

45. Xia H, Ebben J, Ma J, Collins A. Hematocrit levels and hospitalization risk in hemodialysis patients. J Am Soc Nephrol. 1999;10:1309-16.

46. Collins AJ, Ma J, Ebben J. Hospital length of stay is associated with hematocrit level. J Am Soc Nephrol. 1997;8:190A.

47. Locatelli F. The impact of hematocrit levels and erythropoietin treatment on overall and cardiovascular mortality and morbidity: the experience of Lombardy Dialysis Registry. Nephrol Dial Transplant. 1998;13:1642-4. 